\title{
Determining Acid and Metalliferous Drainage Potential of Waste Rock on a Mine*
}

\author{
${ }^{1}$ S. Fosu, ${ }^{1}$ C. Owusu, ${ }^{1}$ F. Ntsiful, ${ }^{1}$ K. Ackah \\ ${ }^{1}$ University of Mines and Technology, Tarkwa, Ghana
}

Fosu S., Owusu C., Ntsiful, F. and Ackah K. (2020), "Determining Acid and Metalliferous Drainage Potential of Waste Rock on a Mine", Ghana Mining Journal, Vol. 20, No. 2, pp. 49-59.

\begin{abstract}
Acid and Metalliferous Drainage (AMD) is recognised as serious environmental problem in the mining industry. This is because environmental issue of AMD poses serious threat to water quality, vegetation cover and social licence of the mining operations. AMD occurs when reactive sulphide bearing materials are exposed to oxidising conditions. It has now become imperative for some mining companies to test sulphide bearing minerals for their AMD potential before major mining excavations are done. This work determines the AMD potential of fifty (50) waste rock samples from a Mine using Acid Base Accounting (ABA) techniques. Mineralogical studies on the sample indicated that the major sulphide mineral assemblages present were pyrite, arsenopyrite and chalcopyrite. Paste $\mathrm{pH}$ showed that $20 \%$ of the samples had undergone weathering and as such AMD generation had already started. Approximately $22 \%$ of the sample had conductivity levels between 1000 to $10,000 \mu \mathrm{S} / \mathrm{cm}$ and this shows a typical AMD chemical characteristic of high salinity. Acid Base Accounting showed that $32 \%$ of the samples were acid generating. Exactly $16 \%$ were non-acid forming and $52 \%$ were uncertain. The analysis showed that the potential for AMD generation exists for the waste rock material and can affect the local environment, specifically water quality if preventive measures are not taken.
\end{abstract}

Keywords: Sulphide, Waste Rock, Acid Base Accounting, Paste pH, Conductivity

\section{Introduction}

One of the major problems facing most mining site environs is the spontaneous acidic effluent discharges into community waters close to mining companies as a result of the mining activities. The discharge termed as Acid and Metalliferous Drainage (AMD) is generated when reactive sulphide minerals (Table 1) chiefly pyrite are exposed to atmospheric oxygen, water and microbial action (Johnson and Hallberg, 2005; Akcil and Koldas, 2006; Kalin et al., 2006; Dold, 2008; Dold, 2017). Sulphide mineral like pyrites go through a binary stage oxidation process, firstly generating ferrous sulphur and sulphuric acid and thereafter, ferric hydroxide (Fig. 1) that is reddish orange with additional sulphuric acid (Naidu et al., 2019).

AMD occurs naturally but mining and land disturbances facilitate its generation rate by increasing the amount of exposed sulphide-bearing materials. The attributes of AMD tend to rely on varying site conditions such as weather, geomorphology and amount of waste materials (Schaider et al., 2014; Nieva et al., 2018). Chemical, biological and physical factors that mainly impact the level of AMD generation includes air (oxygen), rain drop temperature and water saturation levels, microbial activity and degree of metal sulphide exposure (Akcil and Koldas, 2006) Fig. 2. Naturally-occurring bacteria can also accelerate the generation of AMD by aiding in the breakdown of sulphide materials (Akcil and Koldas, 2006; Qureshi et al., 2016).
Table 1 Metal Sulphides with Predominant Acid Producers.

\begin{tabular}{|c|c|}
\hline Metal sulphide & Chemical formula \\
\hline Pyrite & $\mathrm{FeS}_{2}$ \\
\hline Marcasite & $\mathrm{FeS}_{2}$ \\
\hline Pyrrhotite & $\mathrm{Fe}_{1-\mathrm{x}} \mathrm{S}$ \\
\hline Chalcocite & $\mathrm{Cu}_{2} \mathrm{~S}$ \\
\hline Covellite & $\mathrm{CuS}$ \\
\hline Chalcopyrite & $\mathrm{CuFeS}_{2}$ \\
\hline Molybdenite & $\mathrm{MoS}_{2}$ \\
\hline Millerite & $\mathrm{NiS}$ \\
\hline Galena & $\mathrm{PbS}$ \\
\hline Sphalerite & $\mathrm{ZnS}$ \\
\hline Arsenopyrite & FeAsS \\
\hline
\end{tabular}

Source: (Skousen, 1995; Simate and Ndlovu, 2014)

Due to the mineral composition of the sulphidebearing rock, that is, the acid generating minerals, a study of the mineralogy and analysis of the relative percentages of acidic and basic minerals of the rock can be used to predict its acid generating potential (Ofori-Sarpong et al., 2013). With the evolution of metal extraction technologies, the amount of mine wastes produced have increased tremendously, a trend, which will increase even more in the future (Dold, 2017). 


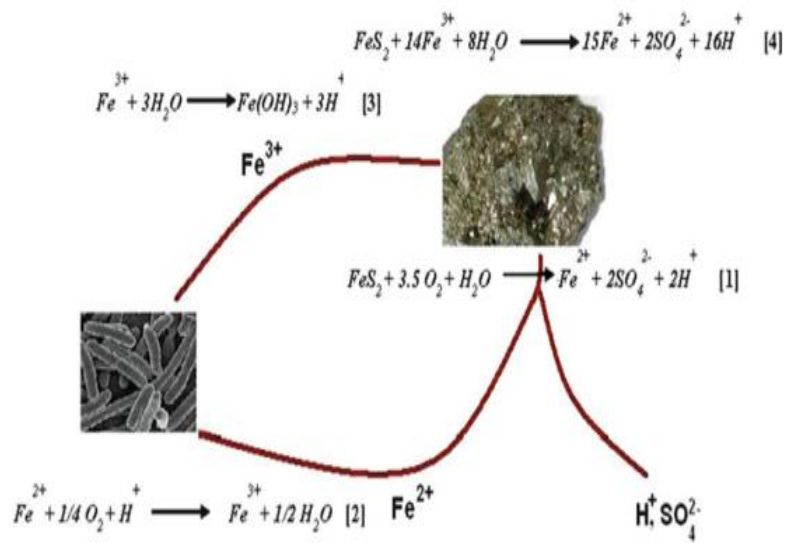

Fig. 1 Pyrite Oxidation Process

Source: (Kleinmann et al., 1981)

The oxidation of sulphide mine waste and the corresponding acidic effluent discharges have been described as the major environmental pollutant of water in many countries that have historic or current mining activities. This is because once an acidgenerating rock is exposed to oxygen and water, the reaction process is difficult to contain or stop, and can continue for years until the sulphide minerals are exhausted (Simate and Ndlovu, 2014; Kefeni et al., 2017). Hence using a more precise method to predicts AMD potential to take proactive measures to prevent its effect on environment is of paramount importance.

Generally, in low $\mathrm{pH}$, water variable concentrations of heavy metals and metalloids are mobilised.
These characteristics can lead to pollution or contamination of both surface and groundwater as well as soils, which consequently affect the biodiversity of the affected area (Nleya et al., 2016) (Fig. 2).

This work seeks to determine the acid and metalliferous drainage potential of waste rock from a mineral bearing concession in Ghana using Acid Base Accounting (ABA) as the predictive tool, which can help to effectively employ preventive measures to curb the menace, protect ecological properties at the mine and surrounding communities.

\section{Resources and Methods Used}

\subsection{Sample Preparation}

Fifty (50) waste rock samples from the mine were received in sample bags. The samples were weathered materials with an average size of $8 \mathrm{~mm}$. Portions of the as-received samples were split for mineralogical studies, total sulphur content and paste $\mathrm{pH}$ determination. The samples were crushed and pulverized to $80 \%$ passing $75 \mu \mathrm{m}$ after which ABA was done to ascertain the acid production potential, neutralization potential and net neutralising potential of the samples in accordance with the Australian Mineral Industries Research Association Limited (AMIRA) protocol (Anon, 2002).

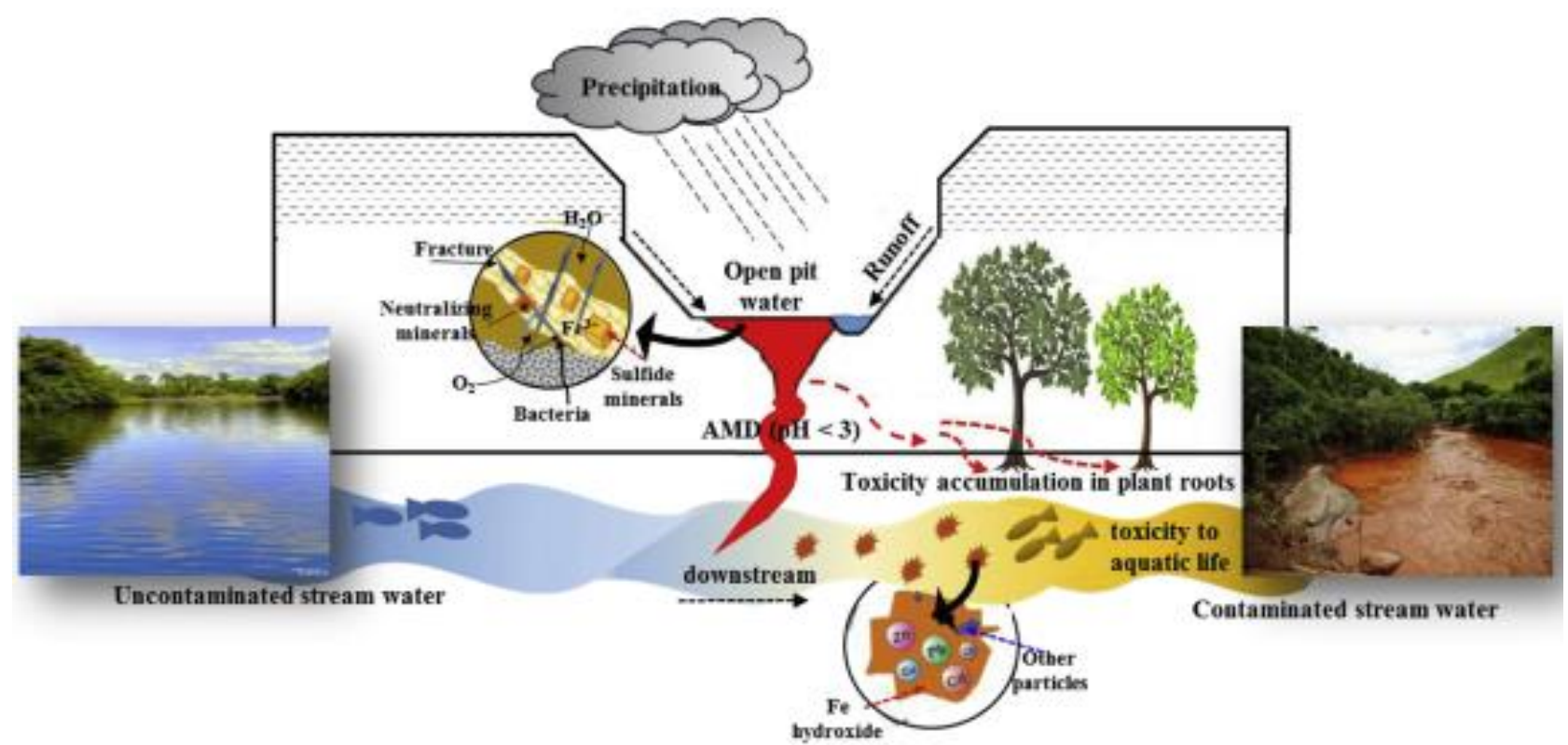

Fig. 2 AMD Generation and Related Contamination Pathway Source: (Naidu et al., 2019) 


\subsection{Mineralogical Analysis}

Mineralogical studies were done by thin and polish section microscopy and XRD determination. Thin section microscopy was done using a LEICA DMC EP Polarizing Microscope. Polish sections were conducted using a Leitz Optical Microscope. Quantitative X-ray diffraction (QXRD) quantified and identified the various mineral phases in the waste rock sample. Prior to the XRD analysis, the samples were placed into a sample cup ensuring that it was packed, flat and levelled with the top of the cup before analysing with Scintag ARL X'tra diffractometer and $\mathrm{Cu} \mathrm{K} \alpha$ radiation $(\lambda=1.5406 \AA$ ). XRD traces were collected between $2^{\circ}$ and $90^{\circ} 2 \theta$ at 0.02 intervals at the rate of $0.24^{\circ}$ per minute. All the mineral peaks were identified using $X$ Powder software and then quantified using SIROQUANT V3 software.

\subsection{Past pH and Conductivity of Samples}

Paste $\mathrm{pH}$ of all the fifty (50) samples was done to determine the current acidity status of the sample (Weber et al., 2006). In this test, $10 \mathrm{~g}$ of each sample was pulped with $20 \mathrm{~mL}$ of deionized water in a beaker. The mixture was allowed to stand for 10 mins, after which the $\mathrm{pH}$ and conductivity values were recorded as the values became stable.

\subsection{Acid Base Accounting (ABA)}

Acid Base Accounting is an analytical technique that generates values to help predict the acid generation and acid-neutralizing potential of rock prior to mining and other large excavations (Anon, 1994). It is also a theoretical balance between the potential for a sample to generate acid and neutralise acid. The ABA's simplest form is known as the Net Acid Producing Potential (NAPP). It involves determining the maximum potential acidity (MPA) and the inherent acid-neutralising capacity (ANC). The procedure helps in determining post-mining water quality. In the acid base accounting technique utilized, the following terms were applied: PAF Potential Acid Forming, PLC -Potential Acid Forming Low Capacity, NAF - Non-Acid Forming, $\mathrm{U}$ - Uncertain.

\subsubsection{Determination of maximum potential acidity (MPA)}

The MPA can be deduced from the sulphur content of a sample. The MPA is determined by multiplying the total sulphur content of the sample by a conversion factor of 30.6 in units of $\mathrm{kg} \mathrm{H}_{2} \mathrm{SO}_{4} / \mathrm{t}$, i.e. $(\mathrm{MPA}=30.6 * \% \mathrm{~S})$ (Weber et al., 2004). The calculation assumes that the measured sulphur content occurs as pyrite reacts under oxidising conditions to produce acid (Anon, 2002).

\subsubsection{Determination of total Sulphur in the samples}

Total sulphur content of a sample is commonly determined by high temperature combustion volumetric technique using LECO SC-144 Titrator.

\subsubsection{Determination of Acid Neutralisation Capacity (ANC)}

The ANC is commonly determined by the Sobek method. This method involves the addition of a known amount of hydrochloric acid $(\mathrm{HCl})$ to an accurately weighed sample, allowing the sample time to react (by heating) and back titrating the mixture with standardized sodium hydroxide $(\mathrm{NaOH})$ to determine the amount of unreacted $\mathrm{HCl}$ (Sobek et al., 1978). A fizz test was performed to determine the volume and concentration of both acid and caustic to be used in the analysis as shown in Table 2. The appropriate volume and concentration of acid as deduced from the fizz test was added to 2 $\mathrm{g}$ of the sample together with $20 \mathrm{~mL}$ of deionized water. The mixture was heated for approximately 2 hrs and titrated with standardized sodium hydroxide. Blanks were prepared in the same manner (Anon, 2002). The ANC value (in $\mathrm{kg} \mathrm{H}_{2} \mathrm{SO}_{4} / \mathrm{t}$ ) was calculated using Eq.1:

$$
\mathrm{ANC}=\left[\mathrm{Y} \times \mathrm{M}_{\mathrm{HCl}} / \mathrm{wt}\right] \times C
$$

where; $\mathrm{Y}=($ Volume of $\mathrm{HCl}$ added $)-($ Volume of $\mathrm{NaOH}$ titrated $\times \mathrm{B}), \mathrm{B}=($ Volume of $\mathrm{HCl}$ in Blank $)$ / (Volume of $\mathrm{NaOH}$ titrated against Blank), $\mathrm{M}_{\mathrm{HCl}}=$ Molarity of $\mathrm{HCl}$, wt $=$ Weight of sample in grams $\mathrm{C}=$ Conversion factor (49.0).

Table 2 Amount of $\mathrm{HCl}$ and $\mathrm{NaOH}$ used in the ANC Test

\begin{tabular}{|c|c|c|c|c|}
\hline Reaction & \multirow{2}{*}{$\begin{array}{c}\text { Fizz } \\
\text { Rating }\end{array}$} & \multicolumn{2}{|c|}{ HCl } & NaOH \\
\cline { 3 - 5 } & & $\begin{array}{c}\text { Molarity } \\
(\mathrm{M})\end{array}$ & $\begin{array}{c}\text { Volume } \\
(\mathrm{mL})\end{array}$ & $\begin{array}{c}\text { Molarity } \\
(\mathrm{M})\end{array}$ \\
\hline No & 0 & 0.5 & 4 & 0.1 \\
\hline Slight & 1 & 0.5 & 8 & 0.1 \\
\hline Moderate & 2 & 0.5 & 20 & 0.5 \\
\hline Strong & 3 & 0.5 & 40 & 0.5 \\
\hline Very & 4 & 0.1 & 40 & 0.5 \\
\cline { 3 - 5 } Strong & 5 & 0.1 & 60 & 0.5 \\
\hline
\end{tabular}

Source: (Anon, 2002)

\subsubsection{Determination of Net Acid Generation (NAG)}

This static method uses hydrogen peroxide to oxidise any sulphides present in the sample. $250 \mathrm{~mL}$ of $15 \%$ hydrogen peroxide $\left(\mathrm{H}_{2} \mathrm{O}_{2}\right)$ was added to 2.5 $\mathrm{g}$ of the sample. The mixture was left undisturbed for $24 \mathrm{hrs}$ after which it was heated for $2 \mathrm{hr}$. 
Deionized water was added to achieve a total volume of $250 \mathrm{~mL}$ after which $\mathrm{pH}\left(\mathrm{NAG}_{\mathrm{pH}}\right)$ and conductivity values were recorded (Anon, 2002). The NAG (in $\mathrm{kg} \mathrm{H}_{2} \mathrm{SO}_{4} / \mathrm{t}$ ) value was calculated using Eq. 2:

$$
\mathrm{NAG}=(49 \times V \times M) / W
$$

where; $\mathrm{V}=$ Volume of $\mathrm{NaOH}$ used in titration, $\mathrm{M}=$ Concentration of $\mathrm{NaOH}$ used, $\mathrm{W}=$ Weight of sample.

\subsubsection{Determination of Net Acid Production Potential (NAPP)}

NAPP is a theoretical calculation commonly used to indicate if a material has a potential to generate AMD. It represents the balance between the capacity of a sample to generate acid (MPA) and its capacity to neutralize acid (ANC). The NAPP was determined by subtracting the ANC from the MPA. Fig. 3 shows the procedure for the NAPP determination of the samples.

\section{Results and Discussion}

\subsection{Mineralogy}

Result of mineralogical analysis is shown in Fig. 4. Some of the mineral assemblages identified were pyrite, arsenopyrite, chalcopyrite and magnetite. The presence of magnetite in the sample could be as result of pyrite alteration, implying that sulphide oxidation leading to acid generation has already began. A, B, C, D depicts arsenopyrite, magnetite, pyrite, and chalcopyrite respectively. This implies that the ore-bearing materials contain sulphide and hence have the potential of generating acid.

Results of the quantitative XRD mineral analysis of the sample are shown in Table 3. The mineralogy of the sample is complex with several mineral phases. Apart from the sulphide minerals phases, there are also important acid neutralisation minerals such as dolomite, quartz and muscovites (Table 3). According to Sverdrup (1990), at $\mathrm{pH}$ range 5 to 7 , these minerals have relative reactivity in acid neutralisation capacity in the order; dolomite (1.0) > muscovite (0.01) > quartz (0.004) and tend to buffer the system in a circum-neutral $\mathrm{pH}$ value.

\section{Sample Preparation}

\section{Basic Screening Tools}

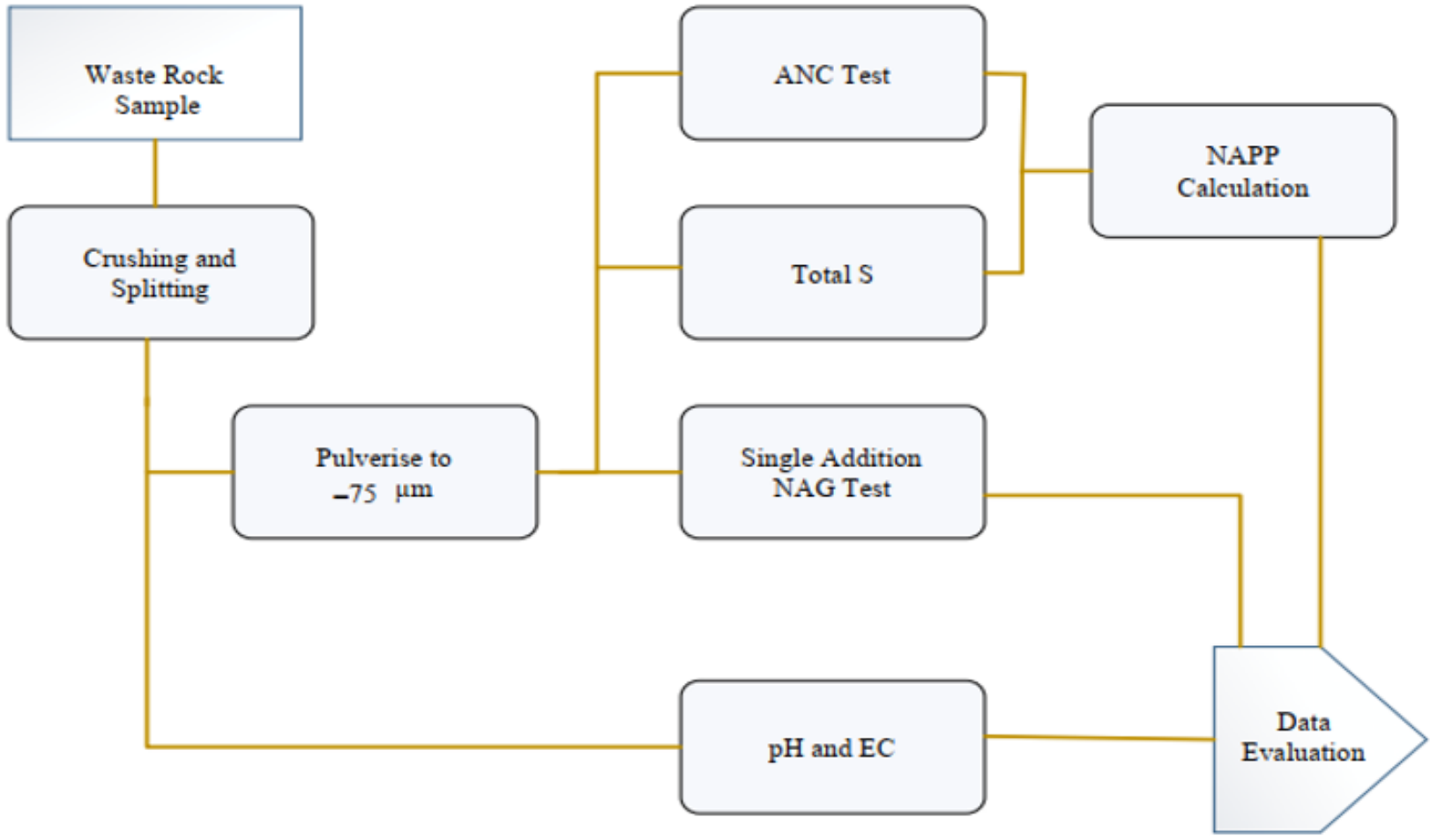

Fig. 3 Representation of Sample Preparation and Screening Tools for ABA Source: (Anon, 2002) 


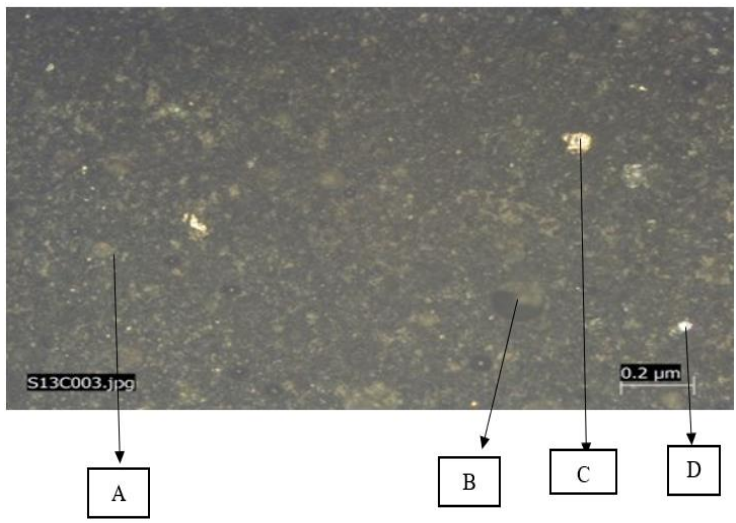

Fig. 4 Photomicrographs (polish sections) Showing Mineralogical Analysis

Table 3 The Distribution of Major Mineral in the Waste Rock Sample as Defined by QXRD

\begin{tabular}{|l|c|}
\hline Minerals & Mass fraction $(\% \mathbf{w} / \mathbf{w})$ \\
\hline Pyrite & 5.20 \\
\hline Arsenopyrite & 4.70 \\
\hline Chalcopyrite & 1.00 \\
\hline Dolomite & 13.01 \\
\hline Quartz & 56.37 \\
\hline Muscovite & 18.90 \\
\hline Magnetite & 0.82 \\
\hline Total & 100 \\
\hline
\end{tabular}

\subsection{Paste pH and Conductivity}

\subsubsection{Paste $\mathrm{pH}$}

Table 4 shows the paste $\mathrm{pH}$ result of the samples. Out of the 50 samples, $20 \%$ (i.e., samples 1, 3, 4, 17, $22,28,31,32,35$ and 39) had paste $\mathrm{pH}$ below 6.5 , implying that, these samples have the potential of generating AMD. Table 4 shows that $80 \%$ of the samples had a paste $\mathrm{pH}$ above 6.5. Paste $\mathrm{pH}$ is a preliminary test conducted to determine the "natural" $\mathrm{pH}$ or the current acidity of the rock mineral sample (Weber et al., 2006). The test is nonvigorous as such only soluble salts and reactive minerals are assessed. Paste $\mathrm{pH}$ provides no indication of the sample's total capacity to generate acidity or alkalinity, but rather provides an indication of the immediate $\mathrm{pH}$ characteristics of the sample should it be mixed with water (Sobek et al., 1978; Ferguson and Morin, 1991). Paste $\mathrm{pH}$ may give an indication of the extent of sulphide oxidation in the sample, which is also a sign of potential weathering of the sample (Weber et al., 2006). According to Weber et al. (2004), samples with paste $\mathrm{pH}<6.5$ have already undergone weathering and therefore would contain acidic sulphate salts.
Such samples will readily release acidity when in contact with water.

\subsubsection{Conductivity}

Fig. 5 shows the conductivity values recorded during the test. $22 \%$ of the samples (i.e., samples 3 , $4,21,22,24,31,32,35,36$ and 39) had electrical conductivity $(6160,6700,2810,4530,1002,2110$, $1652,1505,2440$ and $3610 \mu \mathrm{S} / \mathrm{cm}$ respectively). Conductivity values can be used as a predictive measure to forecast the potential of samples to produce acid and consequently release ions even before analysis to determine the acid generation and neutralising potential of samples are conducted. AMD is associated with electrical conductivity levels between 1000 to $20000 \mu \mathrm{S} / \mathrm{cm}$, as such, samples with electrical conductivity within this range have the potential of releasing high levels of metal concentrations should AMD occur (Sephton and Webb, 2017). Again, the conductivity values of the above-mentioned samples fall within the range of AMD electrical conductivity.

Results from the $\mathrm{pH}$ and electrical conductivity values can be used to predict samples with the potential of generating AMD, even before Acid Base Accounting techniques are employed. It was noticed that samples 3, 4, 22, 31, 32, 35 and 39 had a paste $\mathrm{pH}(6.02,6.22,6.25,3.19,6.15,6.21$ and 6.43 respectively) less than 6.5 and conductivity between 1000 to $20000 \mu \mathrm{S} / \mathrm{cm}$, as such these samples (i.e., samples 3, 4, 22, 31, 32, 35, and 39) have a potential of releasing acidic effluent when exposed to oxidizing conditions.

\subsection{Acid Base Accounting (ABA)}

\subsubsection{Net acid producing potential (NAPP)}

NAPP values can be used as a preliminary indication to determine if a sample will generate acid or not (Anon, 2002). It is also a qualitative measure of the difference between the capacity of a sample to generate acid (MPA) and its capacity to neutralise acid (ANC). A negative NAPP value implies that there are enough neutralizing minerals in the sample to prevent the generation of acid, (i.e. MPA < ANC) and vice versa.

Fig. 6 shows the ANC and MPA values obtained. Sample 47 recorded the highest ANC value of $327.97 \mathrm{~kg} \mathrm{H}_{2} \mathrm{SO}_{4} / \mathrm{t}$ with corresponding MPA value of $8.32 \mathrm{kgH}_{2} \mathrm{SO}_{4} / \mathrm{t}$. Sample 39 recorded the highest MPA value of $74.358 \quad \mathrm{~kg} \quad \mathrm{H}_{2} \mathrm{SO}_{4} / \mathrm{t}$ with corresponding ANC value of $43.40 \mathrm{~kg} \mathrm{H}_{2} \mathrm{SO}_{4} / \mathrm{t}$. 
Table 4 Paste pH of Samples

\begin{tabular}{|c|c|c|c|}
\hline Sample ID & $\mathrm{pH}$ & Sample ID & $\mathrm{pH}$ \\
\hline 1 & 5.68 & 26 & 7.94 \\
\hline 2 & 6.92 & 27 & 6.73 \\
\hline 3 & 6.02 & 28 & 6.32 \\
\hline 4 & 6.22 & 29 & 8.20 \\
\hline 5 & 8.04 & 30 & 8.25 \\
\hline 6 & 7.01 & 31 & 3.19 \\
\hline 7 & 7.15 & 32 & 6.15 \\
\hline 8 & 6.97 & 33 & 8.58 \\
\hline 9 & 7.12 & 34 & 8.35 \\
\hline 10 & 7.62 & 35 & 6.21 \\
\hline 11 & 7.72 & 36 & 6.93 \\
\hline 12 & 7.67 & 37 & 8.13 \\
\hline 13 & 6.70 & 38 & 7.00 \\
\hline 14 & 7.30 & 39 & 6.43 \\
\hline 15 & 7.81 & 40 & 8.33 \\
\hline 16 & 7.79 & 41 & 7.82 \\
\hline 17 & 5.77 & 42 & 9.91 \\
\hline 18 & 8.24 & 43 & 7.75 \\
\hline 19 & 8.14 & 44 & 7.47 \\
\hline 20 & 8.40 & 45 & 8.13 \\
\hline 21 & 7.00 & 46 & 7.85 \\
\hline 22 & 6.25 & 47 & 9.03 \\
\hline 23 & 7.45 & 48 & 7.92 \\
\hline 24 & 7.42 & 49 & 9.05 \\
\hline 25 & 7.73 & 50 & 8.69 \\
\hline
\end{tabular}

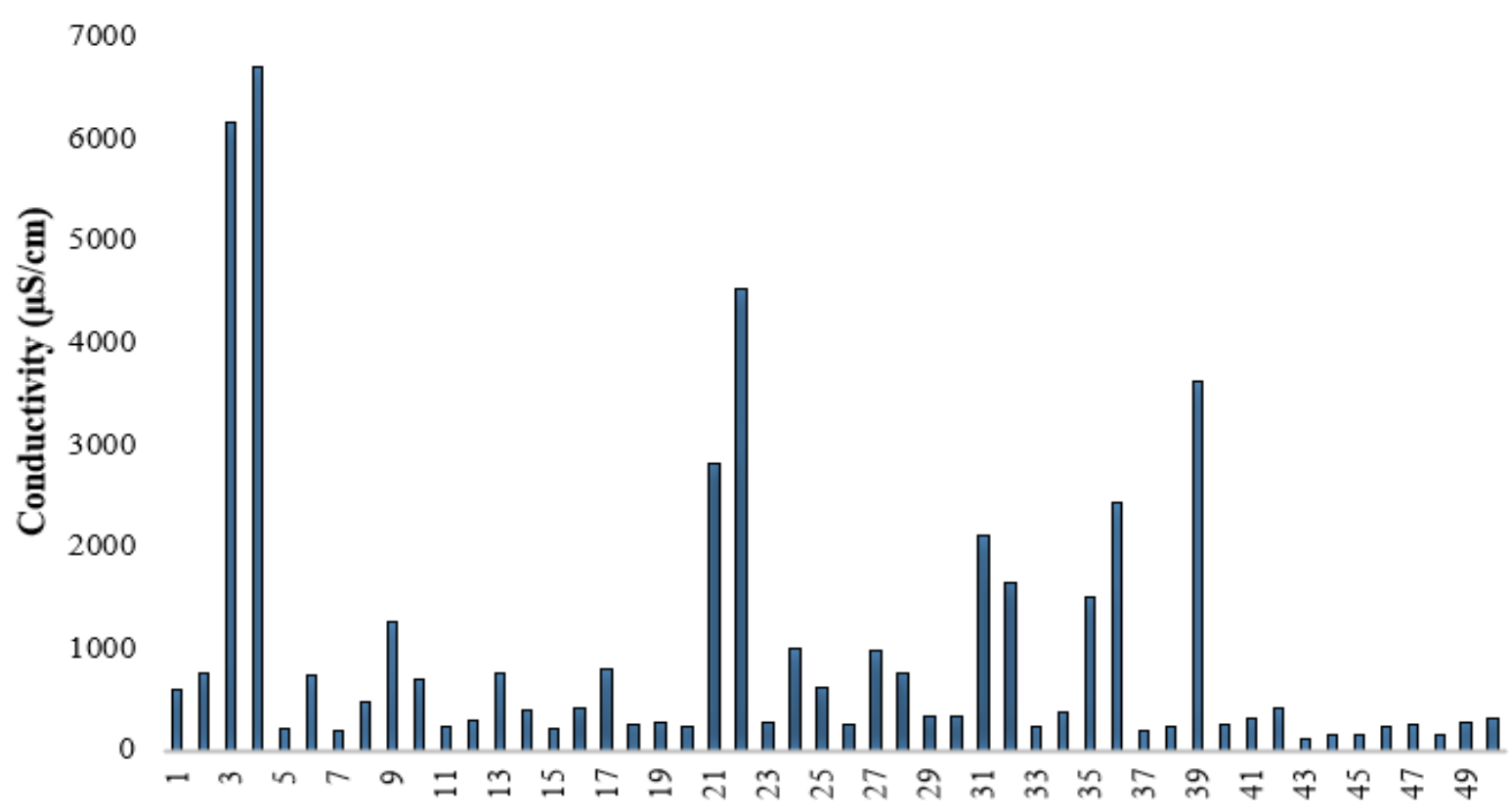

Fig. 5 Conductivity of Samples

\section{Sample ID}




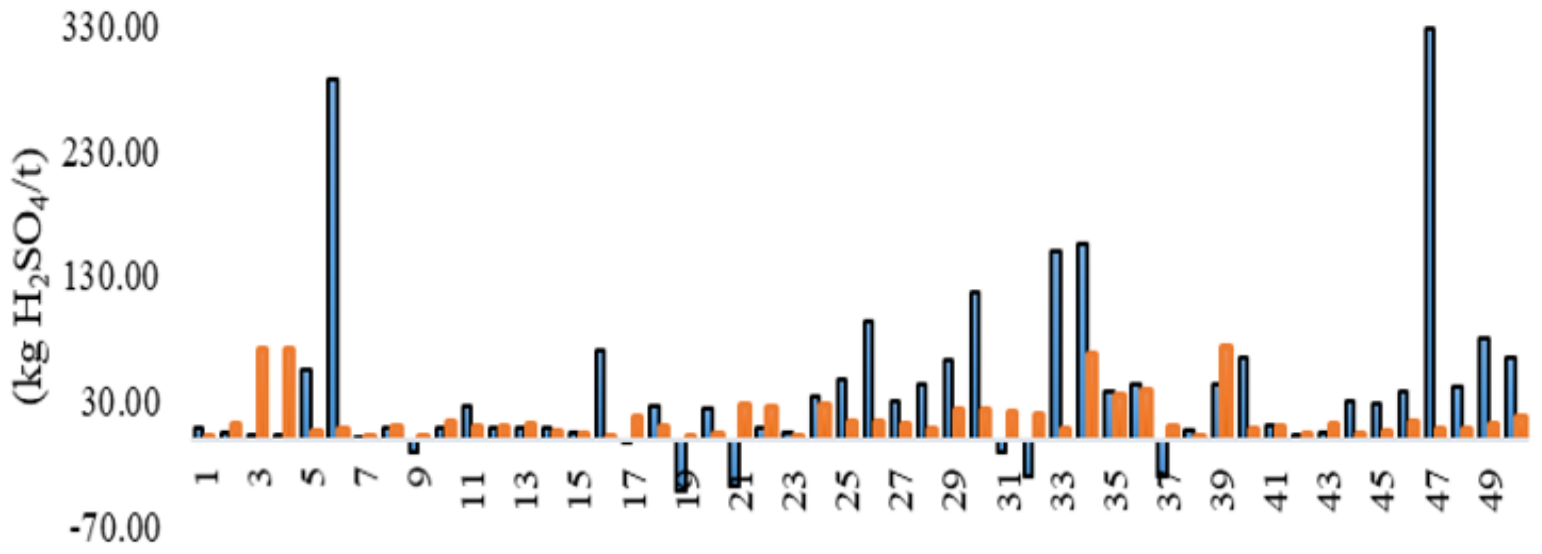

Sample ID

口ANC $\square$ MPA

Fig. 6 ANC and MPA Values of the Samples

From Fig. 6 it can be seen that, samples with high ANC values have low MPA values and vice versa. This affirms the work done by numerous researchers (Schumann et al., 2012; Olds et al., 2016; Assawincharoenkij et al., 2017), indicating that once neutralising minerals are dominant in a sample, little or no acid is produced, since these minerals such as dolomite are able to buffer the acid produced. Similarly, once the MPA values are higher than that of ANC, it implies that the dominant minerals are acid generating hence, acid may be produced upon exposure to favourable oxidising conditions. Figs. 7 and 8 which are graphical representations of the balance between MPA and ANC (MPA - ANC) show in details, samples with the potential of generating acid or not. Fig. 7 shows that $32 \%$ of the samples (i.e., samples $2,3,4,8,9,10,13,17,19,21,22,31,32,37,39$ and 43) have the potential to generate acid with corresponding NAPP values $(6.41,69.79,69.18$, $0.81,11.05,4.36,3.59,20.25,43.66,63.49,16.98$, $32.35,48.51,39.69,30.96$ and $6.54 \mathrm{kgH}_{2} \mathrm{SO}_{4} / \mathrm{t}$ respectively). This implies that, these samples had a higher MPA than ANC.

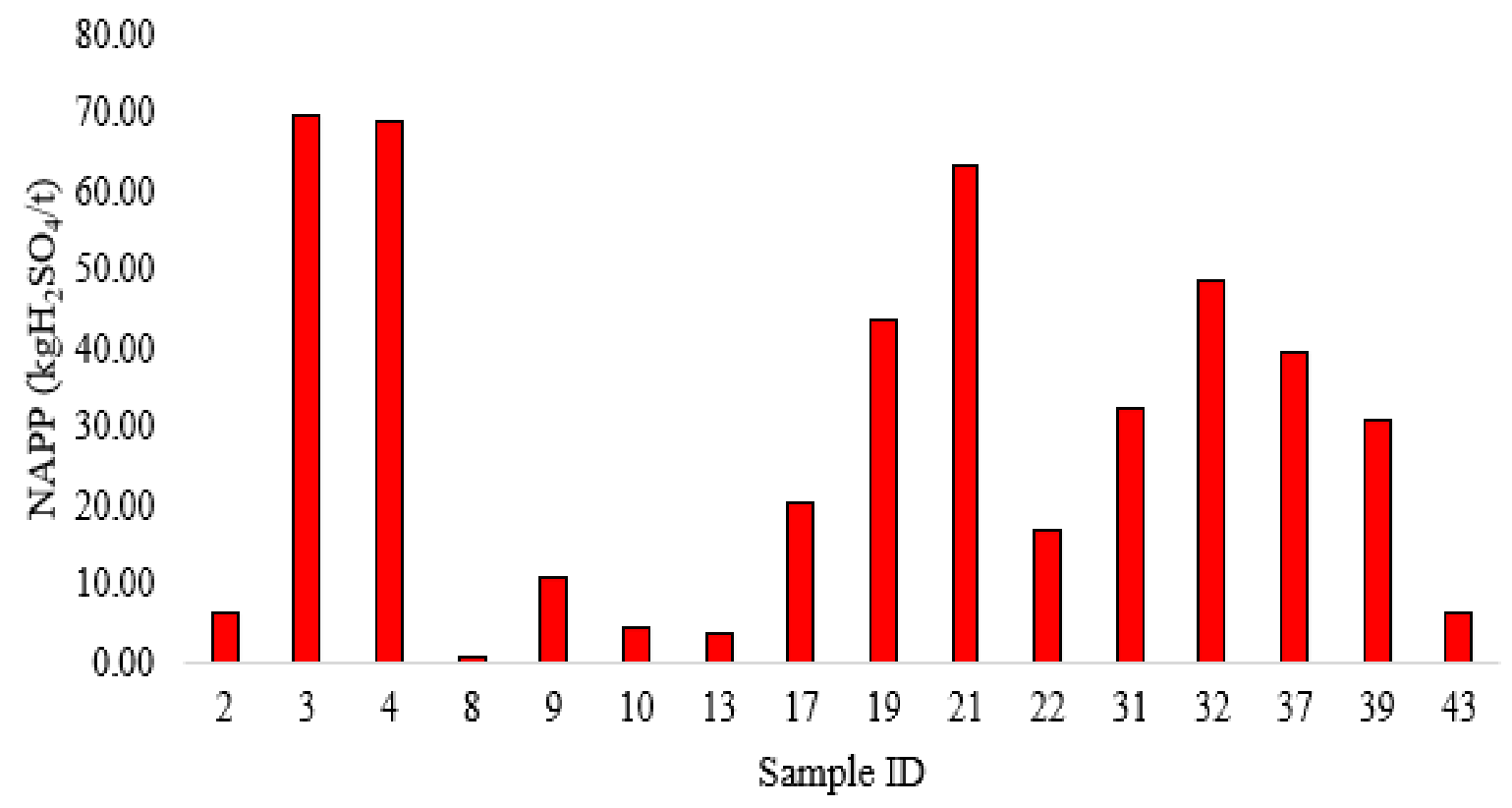

Fig. 7 Samples with the Potential of Generating Acid 


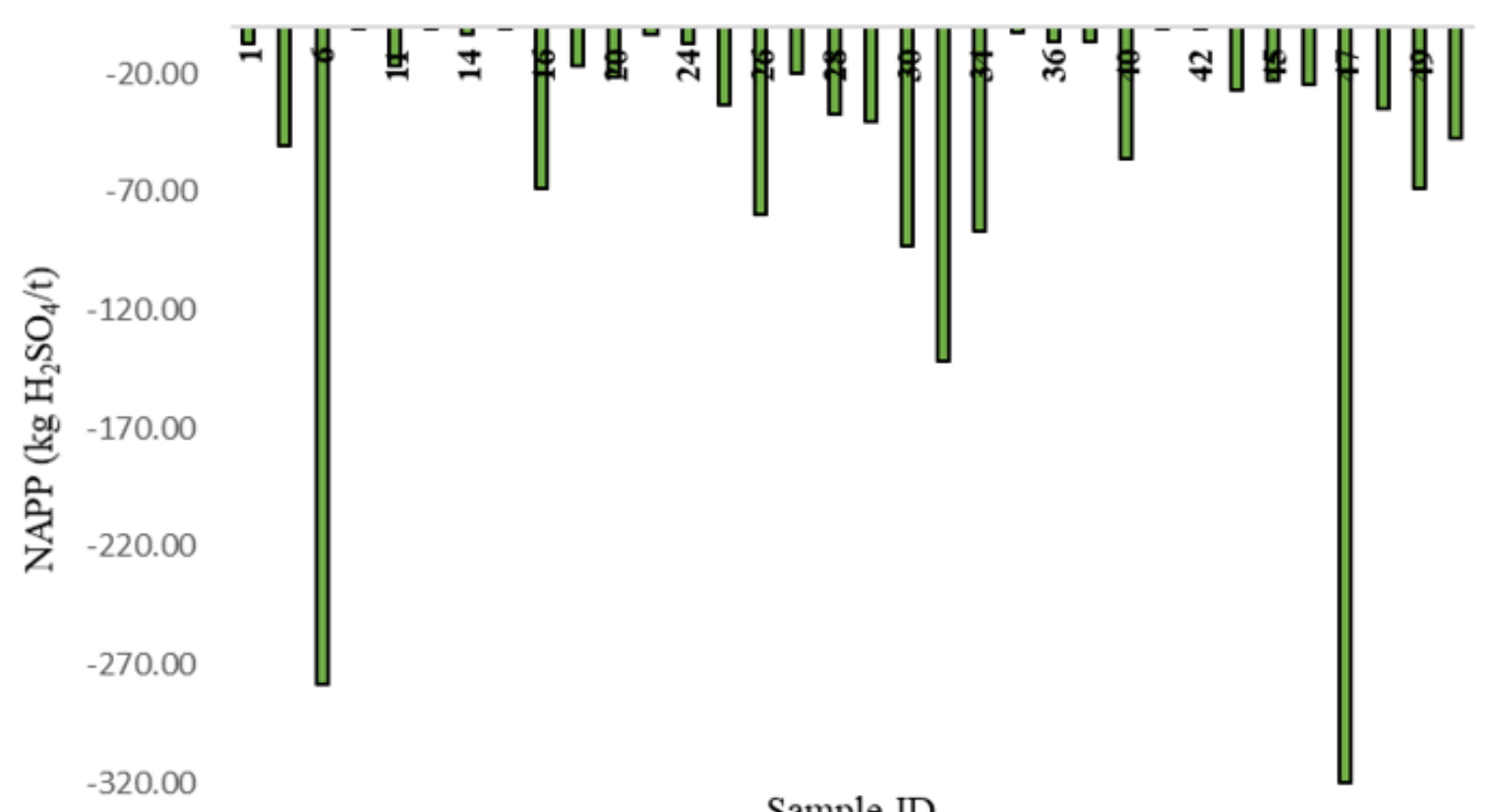

Fig. 8 Samples Unlikely to Generating Acid

Results from Fig. 6 confirmed to an extent that paste $\mathrm{pH}$ and electrical conductivity can be used as a preliminary AMD predictive tool. This is because from Fig. 6, samples 3, 4, 17, 22, 31 and 39 have been indicated to have the potential to generate AMD. These samples recorded paste $\mathrm{pH}$ values below 6.5 (6.02, 6.22, 5.77, 6.25, 3.19 and 6.43 respectively) and electrical conductivity values between 1000 and $20000 \mu \mathrm{S} / \mathrm{cm}(6160,6700,1000$, 4530, 2110 and $3610 \mu \mathrm{S} / \mathrm{cm}$ respectively). Fig. 8 shows that $68 \%$ of the samples may not produce acid. That is to say that, samples $1,5,6,711,12,14$, $15,16,18,20,23$ and 24 just to mention a few, had a greater ANC than MPA, hence a negative NAPP value of $-7.57,50.25,-277.96,-0.54,-16.44,-0.08$, $-3.36,-1.12,-68.85,17.06,-21.10,3.31$ and -7.60 $\mathrm{kgH}_{2} \mathrm{SO}_{4} / \mathrm{t}$ respectively.

\subsubsection{Sample Categorisation}

The Net Acid Generation (NAG) together with the NAPP was used to classify samples into PAF, NAF and Uncertain, following the logical flowchart of Fig. 9 (Anon, 2002). A sample is termed a potential acid forming (PAF) when its NAPP is positive, $\mathrm{NAGpH}$ is less than 4.5 and $\mathrm{NAG}$ value at a NAGpH of 4.5 is greater than 5. A sample is termed a potential acid forming with low capacity (PLC) when its NAPP is positive, its NAGpH is less than 4.5 and its NAG value at a NAGpH of 4.5 is less than 5. A sample is termed a non-acid forming (NAF) when its NAPP is negative, and NAGpH $\geq$ 4.5. On the other hand, an uncertain classification is used when there is an apparent conflict between the NAPP and NAG values. (i.e. samples with a positive $\mathrm{NAPP}$ and $\mathrm{NAGpH} \geq 4.5$ or a negative NAPP with

a $\mathrm{NAGpH}<4.5$ ). Fig. 10 is a graph of $\mathrm{NAGpH}$ against NAPP, it depicts the results deduced from categorizing the samples.

The comparison between NAPP and NAGpH indicated that, samples 3, 4, 9, 13, 17, 19, 21, 22, 32, 37 , and 39 had a positive NAPP, a NAGpH less than 4.5 and a NAG value at NAGpH at 4.5 greater than 5, hence Potential Acid Forming (PAF). Samples 2, $8,10,31$ and 43 had a positive NAPP, a NAGpH less than 4.5 but a NAG value at NAGpH 4.5 less than 5 , hence the samples had a low capacity of producing acid (PLC). Samples 16, 18, 33, 40, 47, 49 and 50 had a negative NAPP and a NAGpH greater than 4.5 hence, Non-acid Forming (NAF). Samples 1, 5, 6, 7, 11, 12, 14, 15, 20, 23, 24, 25, 26, $27,28,29,30$, and 35 had a negative NAPP and a NAGpH less than 4.5 , hence fall under uncertain classification.

Fig. 10 is a geochemical classification plot showing NAGpH versus the NAPP value for the 50 waste rock samples. Potential Acid Forming (PAF), NonAcid Forming (NAF) and Uncertain Classification (UC) domains are indicated. Even though many samples fall within the PAF, that is $22 \%$ of the samples have the potential of producing acid (PAF), $10 \%$ had a low-capacity potential of producing acid (PLC), 16\% were non-acid forming (NAF), but there a number of samples that fall within in the uncertain domain, that is $52 \%$ were uncertain. Hence the NAG test has shown to be a more reliable measure of the acid generating capacity than the NAPP. 


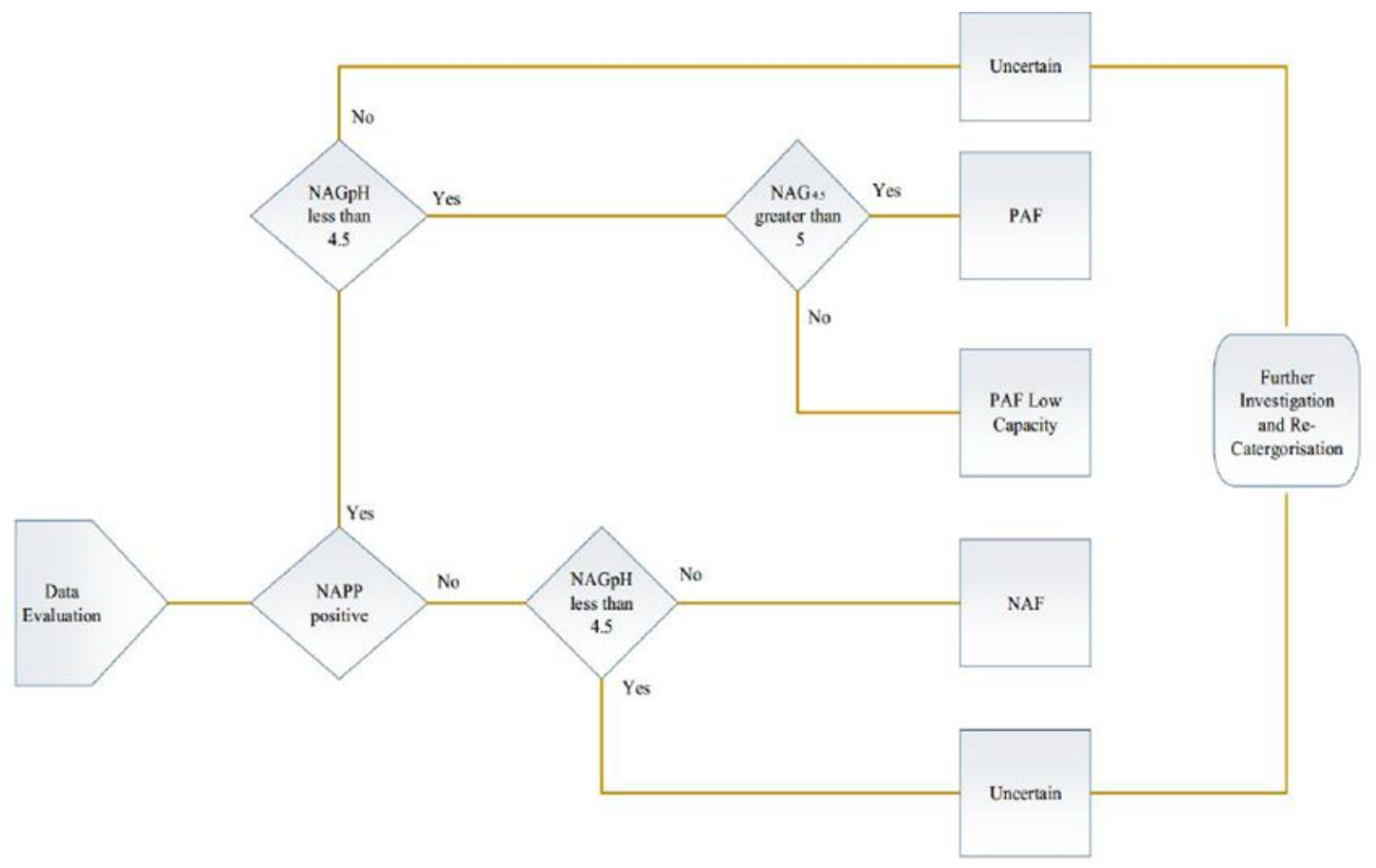

Fig. 9 Flowchart Conditions for Sample Categorisation

Source: (Anon, 2002)

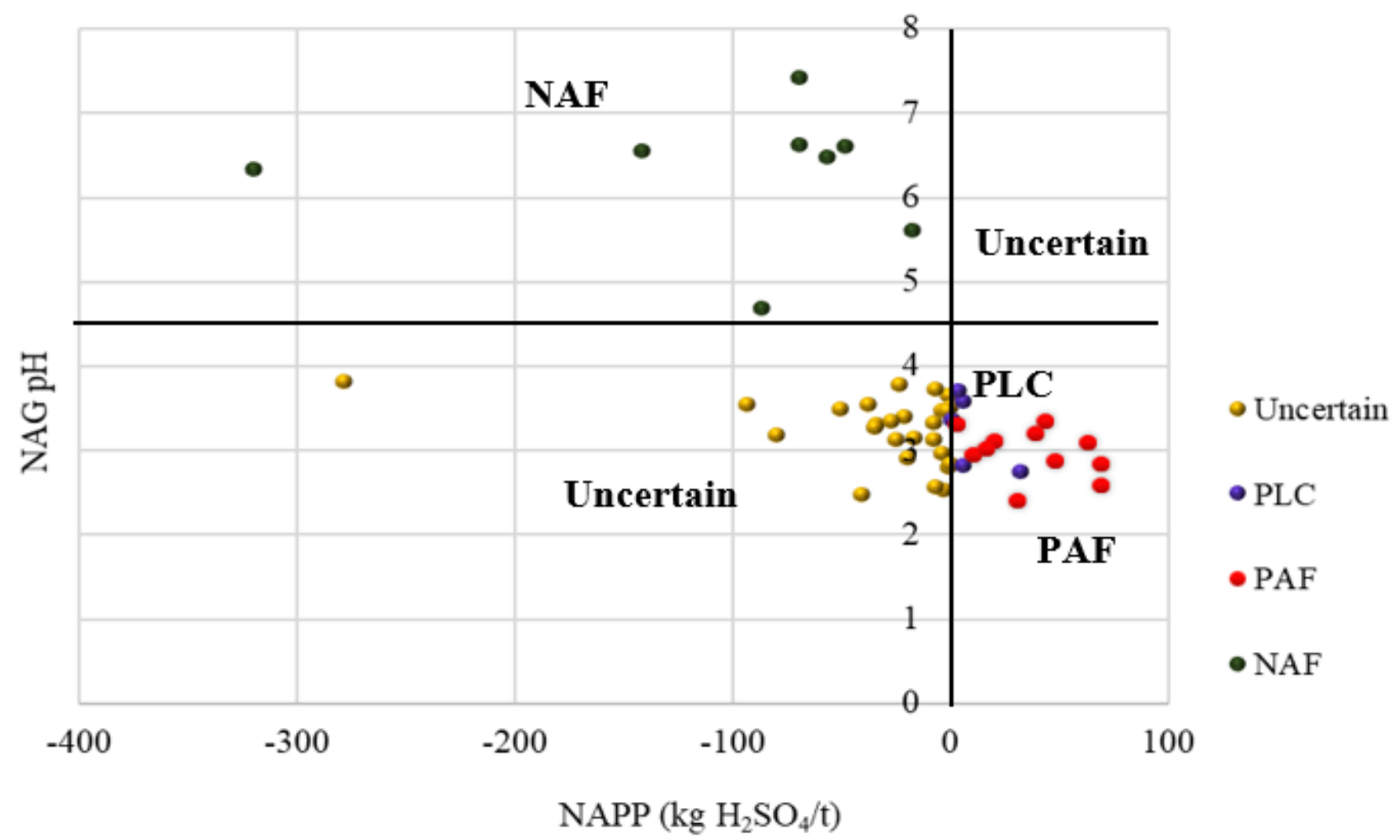

Fig. 10 Geochemical Plot for the Waste Rock Samples showing NAGpH versus NAPP, with AMD Classification Domains Indicated 


\section{Conclusions and Recommendation}

\subsection{Conclusions}

The study investigated the acid and metalliferous drainage potential of waste rocks of a Mine in Ghana using Acid Base Accounting (ABA) as a predictive tool. From the mineralogical analysis of the waste rocks the presence of magnetite could be as result of alteration of pyrite, signifying sulphide oxidation and commencement of acid generation.

The most common sulphide minerals with potential to generate acid identified in the waste rocks were pyrite, arsenopyrite and chalcopyrite. The mineral group identified with the potential to neutralise acid was carbonate (dolomite).

Paste $\mathrm{pH}$ showed that about $20 \%$ of the samples had $\mathrm{pH}$ below 6.5 and had already began generating acid. $22 \%$ of the samples (i.e. samples 3, 4, 21, 22, $24,31,32,35,36$ and 39) had electrical conductivity associated with AMD in the range of 1000 to 20000 $\mu \mathrm{S} / \mathrm{cm}$. Paste $\mathrm{pH}$ and electrical conductivity can be used as a preliminary AMD predictive tool

Results from Acid Base Accounting showed that $22 \%$ of the samples had the potential of generating acid, $16 \%$ were non- acid forming and $52 \%$ were uncertain. Although more than half of the total samples had uncertain classification, the potential of Acid Mine Drainage exists for the waste rock on the mine.

\subsection{Recommendation}

It is recommended that kinetic test should be done on samples with uncertain classification to accurately predict their potential of AMD.

\section{Acknowledgements}

The financial support of the Minerals Engineering and Environmental and Safety Engineering Departments at the University of Mines and Technology, Ghana is highly acknowledged. Also, the help of the Mine X in Ghana for the samples is greatly acknowledged.

\section{References}

Akcil, A. and Koldas, S., (2006), "Acid Mine Drainage (AMD): Causes, Treatment and Case Studies", Journal of cleaner production, Vol. 13, pp. $1139-1145$.

Anon, (1994), "Technical Document: Acid Mine Drainage Prediction", US Environmental
Protection Agency Office of Solid Waste Special Waste Branch, 52 pp.

Anon, (2002), ARD Test Handbook: Prediction and Kinetic Control of Acid Mine Drainage, AMIRA-PS87A,

http://www.amira.com.au/documents/P387A

Protocol, Accessed: April, 15, 2019.

Assawincharoenkij, T., Hauzenberger, C. and Sutthirat, C., (2017), "Mineralogy and geochemistry of tailings from a gold mine in northeastern Thailand", Human and Ecological Risk Assessment: An International Journal, Vol. 23, no.2, pp. 364-387.

Dold, B. (2008), "Sustainability in metal mining: from exploration, over processing to mine waste management" Reviews in Environmental Science and Biotechnology, Vol. 7, pp. 275 - 285.

Dold, B. (2017), "Acid rock drainage prediction: A critical review", Journal of Geochemical Exploration, Vol.172, pp. 120-132.

Ferguson, K.D. and Morin, K.A., (1991), "The Prediction of Acid Rock Drainage Lessons from the Database". Second International Conference on the Abatement of Acidic Drainage Vol. 3, pp. 83-106.

Johnson, D.B., and Hallberg, K.B., (2005), “Acid Mine Drainage Remediation Options: A Review", Science of the Total Environment, Vol. 2, pp. 3-14.

Kalin, M., Fyson, A. and Wheeler, W. N., (2006), "The chemistry of conventional and alternative treatment systems for the neutralisation of acid mine drainage", Science of the Total Environment, Vol. 366, No. 2-3, pp. 395-408.

Kefeni, K.K., Msagati, T.A. and Mamba, B.B., (2017), "Acid Mine Drainage: Prevention, Treatment Options, and Resource Recovery: A Review", Journal of Cleaner Production, Vol. 3, pp. 475-493.

Kleinmann, R. L. P., Crerar, D. A. and Pacelli, R. R., (1981), "Biogeochemistry of acid mine drainage and a method to control acid formation", Mining Engineering, Vol. 33, no.3, pp. $300-306$.

Naidu, G., Ryu, S., Thiruvenkatachari, R., Choi, Y., Jeong, S. and Vigneswaran, S., (2019), "A critical review on remediation, reuse and resource recovery from acid mine drainage", Environmental Pollution, Vol. 247, pp. 11101124.

Nieva, N. E., Borgnino, L. and Garcia, M. G., (2018), "Long term metal release and acid generation in abandoned mine wastes containing metal-sulphides", Environmental Pollution, Vol. 242, pp. 264-276.

Nleya, Y., Simate, G.S. and Ndlovu, S., (2016), "Sustainability Assessment of the Recovery and Utilisation of Acid from Acid Mine Drainage", Journal of Cleaner Production, Vol. 113, pp. 1727. 
Ofori-Sarpong, G., Osei, K. and Amankwah, R.K., (2013), "Ascertaining the Acid Mine Drainage Potential of a Mineral Concession in SouthWestern Ghana", International Journal of Environmental Monitoring and Analysis, Vol. 1, pp. 34-39.

Olds, W. E., Weber, P. A., Pizey, M. H. and Pope, J., (2016), "Acid mine drainage analysis for the reddale coal mine, Reefton, New Zealand", New Zealand Journal of Geology and Geophysics, Vol. 59, no.3, pp. 341-351.

Qureshi, A., Maurice, C. and Öhlander, B., (2016), "Potential of Coal Mine Waste Rock for Generating Acid Mine Drainage", Journal of Geochemical Exploration, Vol. 3, pp. 44-54.

Schaider, L. A., Senn, D. B., Estes, E. R., Brabander, D. J. and Shine, J. P., (2014), "Sources and fates of heavy metals in a mining-impacted stream: temporal variability and the role of iron oxides", Science of the Total Environment, Vol. 490, pp. 456-466.

Schumann, R., Stewart, W., Miller, S., Kawashima, N., Li, J. and Smart, R., (2012), "Acid-base accounting assessment of mine wastes using the chromium reducible sulfur method", Science of the Total Environment, Vol. 424, pp. 289-296.

Sephton, M.G. and Webb, J.A., (2017), "Application of Portland Cement to Control Acid Mine Drainage Generation from Waste Rocks", Applied Geochemistry, pp. 143-154.

Simate, G.S. and Ndlovu, S., (2014), “Acid Mine Drainage: Challenges and Opportunities", Journal of Environmental Chemical Engineering, Vol. 3, pp. 1785-1803.

Skousen, J. G., (1995), "Acid mine drainage", Green Lands, Vol. 25, No. 2, pp. 52-55.

Sobek, A.A. (1978), "Field and laboratory methods applicable to overburdens and mine soils", Industrial Environmental Research Laboratory, Office of Research and Development, US Environmental Protection Agency, 204 pp.

Sverdrup, H. U., (1990), "The kinetics of base cation release due to chemical weathering", Lund University Press, $245 \mathrm{pp}$.

Weber, P.A., Stewart, W.A., Skinner, W.M., Weisener, C.G., Thomas, J.E. and Smart, R.S.C., (2004), "Geochemical Effects of Oxidation Products and Framboidal Pyrite Oxidation in Acid Mine Drainage Prediction Techniques", Applied Geochemistry, Vol. 12, pp. 1953-1974.

Weber, P.A., Hughes, J.B., Conner, L.B., Lindsay, P. and Smart, R., (2006), "Short-Term Acid Rock Drainage Characteristics Determined by Paste $\mathrm{pH}$ and Kinetic NAG Testing: Cypress Prospect, New Zealand", In: $7^{\text {th }}$ International Conference on Acid Rock Drainage (ICARD), St. Louis, North America, pp. 2289-2310.

\section{Authors}

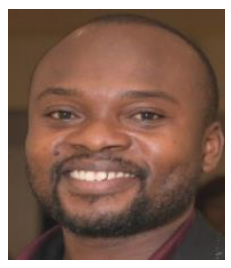

S. Fosu is currently a Senior Lecturer at the University of Mines and Technology, Tarkwa, Ghana. He holds a $\mathrm{PhD}$ in Minerals and Materials Engineering from University of South Australia and a BSc (Hons) Degree in Minerals Engineering from University of Mines and Technology, Tarkwa, Ghana. He is a member of West African Institute of Mining, Metallurgy and Petroleum (WAIMM). His research interest is in the areas of Environmental Chemistry and Pollution, Water and Wastewater Treatment, Ore Characterisation and Process Mineralogy, Mineral Flotation and Aqueous Metallurgy, Simulation and Computer-Aided Process Control.

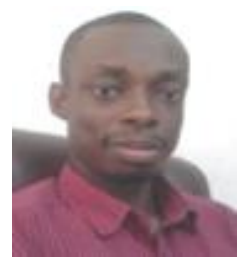

C. Owusu is currently a Senior Lecturer and Researcher in the Minerals Engineering Department, University of Mines and Technology (UMaT), Tarkwa, Ghana. He holds a PhD in Minerals and Materials Engineering from the University of South Australia (UniSA) and a BSc (Hons) Degree in Minerals Engineering from UMaT. He is a member of the West African Institute of Mining, Metallurgy and Petroleum (WAIMM). His current research interest includes oxygen optimization in gold processing, fine particle flotation of sulphide minerals, surface chemistry of minerals, statistical analysis and modelling of metallurgical data.

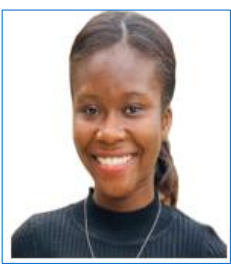

Assessment.

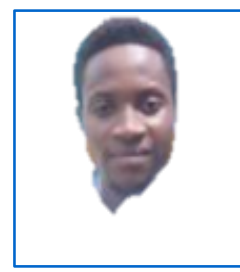

temperature processes in metallurgy.
F. Ntsiful is currently an MPhil Student in the Mining Engineering Department at the University of Mines and Technology (UMaT), Trakwa, Ghana. She holds a BSc (Hons) Degree in Environmental and Safety Engineering from UMaT. Her research interests are Wastewater Treatment, Occupational Health Management and Environmental Impact

K. Ackah is currently a Research Assistant in the Minerals Engineering Department, University of Mines and Technology (UMaT), Tarkwa, Ghana. He holds a BSc (Hons) Degree in Minerals Engineering from UMaT. He has interest in research works pertaining to mineral processing including froth flotation, hydrometallurgy and higher 